\title{
Pengembangan Instrumen Penilaian Supervisi Manajerial Kepala Sekolah PAUD Berbasis Website
}

\author{
Dian Widi Yussanti, Yari Dwikurnaningsih \\ dianwidiyussanti@gmail.com,yari.dwikurnaningsi@uksw.edu \\ Universitas Kristen Satya Wacana \\ The Development Of A Website-Based Managerial Supervision Instrument \\ For Early Childhood School Principals
}

\begin{abstract}
The purpose of this study is to develop website-based managerial supervision assessment instruments to help the duties of kindergarten supervisors in carrying out supervision managerial. This type of research refers to the Borg and Gall R\&D model, modified by Sugiyono. The development research covers potentials and problems, data collection, product design, design validation, design revision, product trials, product revisions. The result of this research is Website-Based Managerial Supervision of School Principal Supervision Assessment Instrument or InPeSiM, guidelines for using InPeSiM for Supervisors and Principals. Based on the results of expert validation, InPeSiM was declared to be very complete and worth testing. Whereas in the field trial, Supervisor stated that the product was very good to used in managerial supervision.
\end{abstract}

Keywords: Assessment Instruments, Managerial Supervision, Website, InPeSiM

Received date: 29 April 2020

Article Info

Revised date: 8 Mei $2020 \quad$ Accepted date: 24 September 2020

\section{PENDAHULUAN}

Supervisi adalah kegiatan yang dilaksanakan oleh seorang supervisor. Selanjutnya yang bertugas sebagai supervisor disini adalah kepala sekolah dan pengawas/penilik sekolah. Di dalam lampiran Peraturan Menteri Pendidikan dan Kebudayaan nomor 143 tahun 2014 tentang petunjuk teknis Pelaksanaan Jabatan Fungsional Pengawas Sekolah Dan Angka Kreditnya menjelaskan bahwa pengawas sekolah adalah seseorang yang mendapatkan wewenang untuk melaksanakan pengawasan, penilaian, pembinaan di sekolah TK, SD, maupun Sekolah Menengah, sehingga satuan pendidikan dapat melaksanakan tugasnya dengan baik dan bertanggung jawab.

Jabatan Fungsional Pengawas Sekolah dan Angka Kreditnya diatur dalam Peraturan Menteri Negara Pendayagunaan Aparatur Negara Dan Reformasi Birokrasi Nomor 21 Tahun 2010. Peraturan ini menyatakan bahwa sasaran pengawasan yang dimaksud pada ayat (I) adalah untuk taman kanakkanak/ raudathul athfal dan sekolah dasar/madrasah ibtidaiyah paling sedikit 10 satuan pendidikan dan/atau 60 (enam puluh) guru. Juga dikatakan di dalam PP no 74 tahun 2008 bahwa lembaga binaan pengawas Taman Kanak-kanak paling sedikit 10 sekolah dan paling banyak 15 sekolah. Akan tetapi Slameto (2016) di dalam penelitiannya menemukan bahwa satu orang pengawas harus melakukan pengawasan terhadap 16 Sekolah. Slameto (2016) menjelaskan bahwa kekurangan tenaga pengawas menjadi kendala dalam melaksanakan tupoksinya.

Dapat juga dilihat dari data statistik guru dan taman kanak-kanak di kota Salatiga, jumlah lembaga Taman kanak-Kanak di kota Salatiga adalah 85 lembaga. Secara keseluruhan, jumlah seluruh tenaga pengajar yang terdaftar dalam keanggotaan IGTKI kota Salatiga adalah 350 guru. Sedangkan jumlah pengawas TK di kota Salatiga adalah 2 orang. Kota Salatiga terdiri dari 4 kecamatan. Dua kecamatan memperoleh binaan dari satu pengawas. Jadi, dapat dilihat dari jumlah rasio pembagian sekolah dan guru binaan, kondisi pengawasan di kota Salatiga tidak sesuai dengan PP no 74 tahun 2008. Rasio guru binaan dengan jumlah pengawas Taman Kanak-Kanak yang mempunyai rentang sangat jauh, menghambat kinerja pegawas. Kualitas dari supervisi tidak akan terjamin jika seorang pengawas memiliki beban kerja yang berlebihan. 
Seperti penelitian Slameto (2016) tentang Supervisi Pendidikan Oleh Pengawas Sekolah mengatakan bahwa dalam melaksanakan tugas dan fungsinya, pengawas sekolah mengalami kendala. Kendala tersebut adalah terbatasnya jumlah pengawas, guru binaan yang berlebih dan kurangnya pelaksanaan supervisi di sekolah-sekolah. Rendahnya keahlian pengawas sekolah didalam merencanakan program supervisi, ketidaksesuaian kualifikasi pengawas dengan kualifikasi guru masing-masing bidang studi, kurangnya keahlian pengawas dalam penggunaan teknologi informasi, terbatasnya sarana prasarana yang mendukung, ditambah lagi dengan manipulasi penyampaian informasi dari pihak sekolah kepada pengawas sekolah saat pengawasan berlangsung juga merupakan kendala dalam melaksanakan tugas pengawas sebagai supervisor.

Hasil penelitian dari Arikunto (2006), menuliskan bahwa instrumen penilaian yang dipakai oleh pengawas dalam penyelenggaraan supervisi terhadap sekolah adalah pedoman observasi, angket, kunjungan kelas/sekolah. Dan semua instrumen tersebut dilaksanakan secara manual, belum menyatu dengan database dan belum diselenggarakan secara online.

Sedangkan pendapat Rochaety (2006) menyatakan bahwa perkembangan pendidikan yang akan datang membutuhkan teknologi informasi yang tidak hanya sebagai sarana pendukung tetapi sebagai hal yang utama dalam meningkatkan dunia pendidikan di Indonesia untuk dapat bersaing di pasar global.

Dari hasil penelitian Slameto (2016) dan Arikunto (2006) dapat kita ketahui bahwa pelaksanaan supervisi manajerial oleh pengawas sekolah memiliki beberapa kelemahan seperti kurangnya tenaga pengawas, kurangnya pengetahuan IT pengawas sekolah dan juga instrumen supervisi yang masih dilakukan secara manual. Kelemahan tersebut diatas juga ditemukan didalam pelaksanaan supervisi manajerial kepala sekolah PAUD di kota Salatiga.

Berdasarkan beberapa kelemahan pada instrumen dan dokumen penilaian supervisi manajerial yang masih manual dan membutuhkan waktu yang lama dalam proses penilaiannya, kurangnya tenaga pengawas TK dalam melaksanakan supervisi dan juga tidak adanya instrumen yang hanya dikhususkan untuk Taman kanak-kanak, melalui penelitian ini akan dikembangkan instrumen penilaian supervisi manajerial berbasis website yang sesuai dengan kebutuhannya, yaitu untuk PAUD. Pengembangan instrumen penilaian supervisi manajerial berbasis website atau InPeSiM ini diharapkan dapat membantu pengawas TK untuk menjalankan tupoksinya sebagai supervisor.

\section{KAJIAN PUSTAKA}

Supervisi manajerial adalah kegiatan penilaian didalam aspek-aspek yang mendukung proses belajar dan mengajar. Direktorat Tenaga Kependidikan (2009) menyatakan pengertian supervisi manajerial adalah supervisi yang berhubungan dengan bagian pengelolaan sekolah yang meliputi tentang perencanaan, koordinasi, pelaksanaan, penilaian, pengembangan kompetensi sumberdaya manusia (SDM) kependidikan dan sumberdaya lainnya.

Shinta (2015) menyatakan bahwa tujuan dari supervisi adalah memberikan bantuan dan pembinaan terhadap sekolah guna meningkatkan kualitas sebuah sekolah. Supervisi yang dilaksanakan oleh pengawas adalah suatu usaha untuk memberikan stimulasi, mengkoordinasi, dan membimbing secara berkelanjutan perkembangan pengajar di sebuah sekolah, baik secara perorangan maupun kelompok, agar lebih memahami dan lebih efisien dalam melaksanakan semua inti dari pengajaran. Sehingga dengan ini, para guru dan tenaga pendidikan dapat menstimulasi dan membimbing perkembangan siswa secara berkelanjutan serta berkompeten dan lebih cakap berperan serta dalam masyarakat demokrasi modern.

Supervisi sangat dibutuhkan untuk perkembangan sekolah. Pengaruh supervisi sangat besar dampaknya terhadap perkembangan sekolah itu sendiri. Di dalam penelitian Rachmati (2016) tentang Pengaruh Supervisi Pendidikan Terhadap Kinerja Guru Pada Sekolah Dasar di Lingkungan Dinas Pendidikan Kota Bandung Gugus 19 dan 20 Kota Bandung, menyatakan bahawa supervisi pendidikan yang dilakukan oleh supervisor memberikan pengaruh yang positif dan signifikan terhadap perubahan kinerja guru. Ini ditunjukkan dengan nilai koefisien korelasi sebesar 0,600 dan koefisien determinan sebesar 0,360 atau 36\% dan sisanya dipengaruhi oleh faktor lain sebesar 0,640 atau 64\% dengan hasil uji F sebesar 18,595 yang berarti signifikan.

Oleh karena pentingnya pelaksanaan supervisi seperti yang dinyatakan diatas, dalam melaksanakan kewajibannya, seorang pengawas sangat membutuhkan suport dan bantuan dari berbagai 
komponen pendidikan, termasuk di dalamnya dukungan dari teknologi. Penggunaan teknologi diharapkan akan memperingan pelaksanaan tugas pengawas sebagai supervisor. Teknologi yang dimaksud adalah teknologi sistem informasi manajerial.

\section{Sistem Informasi Manajerial}

Menurut Baharudin (2010), perkembangan teknologi informasi yang berkembang dengan cepat pada saat ini sangat berpengaruh terhadap dunia pendidikan. Untuk dapat meningkatkan mutu pendidikan, lembaga pendidikan harus dapat menyesuaikan dengan perkembangan teknologi, terkhususnya dalam proses penilaian.

Sistem informasi manajerial sesungguhnya menurut Lipursari (2013) adalah sebuah sub sistem yang merupakan bagian dari sebuah sistem lain yang lebih besar. Sistem informasi tidak dapat dirancang dan dioperasikan secara terpisah dari sub sistem yang lain.

Sistem informasi mempunyai banyak manfaat. Seperti yang dituliskan oleh Prasojo (2005) bahwa SIM berbasis komputer dapat mengatasi kendala-kendala yang terdapat dalam suatu aktivitas pembelajaran. Kendala tersebut dapat diselesaikan dengan cepat dan tepat sehingga tujuan sebuah lembaga dapat tercapai.

Manfaat lainnya disampaikan oleh Lipursari (2013) yaitu sistem informasi manajemen dapat membantu pengambilan keputusan. SIM dapat memberikan segala informasi yang memungkinkan dapat memberi pemimpin pertimbangan alternatif dalam membuat sebuah keputusan penting.

Wiguna (2017) juga menambahkan bahwa manfaat SIM dalam pelaksanaannya sangat membantu dalam meningkatkan efektivitas dan efisiensi kerja sekolah. Efektifitas dan efisiensi khususnya terjadi dalam melaksanakan aktivitas layanan data dan informasi administrasi sekolah dengan cara mengumpulkan, mengolah, menyimpan, menyebarkan dan memanfaatkan data dan informasi yang akurat, tepat waktu, relevan dan lengkap untuk pencapaian tujuan pendidikan yang efektif serta meningkatkan kualitas dan perbaikan status pendidikan.

Sejalan dengan penelitian Arham (2016), tentang keefektifan teknologi dalam meningkatkan hasil belajar siswa, menyatakan bahwa teknologi, dalam hal ini media interaktif, sangat efektif dengan ditunjukkan peningkatan hasil belajar siswa sebesar 83,33\% dengan kategori sedang dan 16,67\% kategori tinggi.

Dengan memakai teknologi, terkhususnya pelaksanaan supervisi secara online akan sangat membantu pengawas dalam mengerjakan tugas dan tanggung jawabnya. Para pengawas yang kekurangan waktu dan juga tenaga dapat melakukan supervisi secara online. Penilaian online tidak membutuhkan kehadiran pengawas secara fisik. Pengawas tidak perlu mengagihkan waktu khusus untuk dapat hadir di sekolah tersebut. Disamping itu dalam waktu yang bersamaan, supervisi dapat dilakukan oleh banyak kepala sekolah. Efisiensi waktu dan tenaga diberikan oleh penilaian secara online.

Seperti penelitan Slameto (2016) tentang Supervisi Pendidikan Oleh Pengawas Sekolah mengatakan bahwa kendala yang dihadapi pengawas sekolah dalam melaksanakan tugas dan fungsinya adalah kurangnya tenaga pengawas, banyaknya guru yang harus dibina dan kurangnya intensitas supervisi. Slameto menyatakan bahwa satu orang pengawas harus melakukan pengawasan terhadap 16 Sekolah Menengah Atas.

Kurangnya pengetahuan dan keterampilan TIK oleh pengawas,seperti yang disampaikan Syawal (2013) dalam penelitian Evaluasi Kinerja Pengawas Sekolah Dalam Melakukan Supervisi Penyelenggaraan Pendidikan SD di Kota Tidore Kepulauan, juga sangat mempengaruhi kinerja pengawas sekolah. Syawal (2013) mengatakan berdasarkan hasil analisis data memperlihatkan bahwa 75\% pengawas Sekolah Dasar di Kota Tidore Kepulauan yang mengatakan bahwa kendala yang terjadi didalam melaksanakan tugas pengawasan salah satunya adalah kurangnya pengetahuan dan keterampilan pengawas tentang teknologi informatika dalam hal ini komputer dan internet.

Dikuatkan oleh Istiyarti (2014), yang dungkapkan dalam jurnalnya tentang Pemanfaatan TIK untuk Pembelajaran, bahwa SDM perlu disiapkan untuk dapat meningkatkan mutu pendidikan di Indonesia terkhususnya dalam proses belajar dan mengajar.

Menurut hasil penelitian Arikunto dkk (2006),dalam Jurnal Penelitian Bappeda Kota Yogyakarta, menuliskan bahwa instrumen penilaian yang dipakai oleh pengawas dalam penyelenggaraan supervisi terhadap sekolah adalah pedoman observasi, angket, kunjungan kelas/sekolah. Dan semua instrumen tersebut dilaksanakan secara manual, belum menyatu dengan database dan belum diselenggarakan secara online. 
Sedangkan pendapat Rochaety dkk. (2006) menyatakan bahwa perkembangan pendidikan yang akan datang membutuhkan teknologi informasi yang bukan hanya sebagai sarana pendukung tetapi sebagai hal yang utama dalam meningkatkan dunia pendidikan di Indonesia untuk dapat bersaing di pasar global.

Berdasarkan beberapa kelemahan pelaksanaan supervisi manajerial oleh pengawas TK di Dinas Pendidikan Kota Salatiga pada saat ini, dimana instrumen dan dokumen penilaian masih manual dan membutuhkan waktu yang lama dalam proses penilaiannya, ditambah lagi dengan kurangnya tenaga pengawas TK dalam melaksanakan supervisi dan juga tidak adanya instrumen yang hanya dikhususkan untuk Taman kanak-kanak, melalui penelitian ini dikembangkanlah instrumen penilaian supervisi manajerial berbasis website yang sesuai dengan kebutuhannya, yaitu untuk PAUD.

Pengembangan instrumen penilaian supervisi manajerial berbasis website atau InPeSiM ini diharapkan dapat membantu pengawas TK untuk menjalankan tupoksinya sebagai supervisor.

\section{Instrumen Penilaian Supervisi Manajerial berbasis Website}

Website dikembangkan dengan mengunakan MySQL. Menurut Madcom (2011) mengatakan bahwa My Structured Query Language (MySQL) adalah sebuah perangkat lunak untuk sistem pengelola basis data atau sering disebut Data Base Management System (DBMS). Data base MySQL merupakan database yang memiliki sumber terbuka. Sistem pengembangan ini tidaklah dikoordinasi oleh individu atau sebuah lembaga namun oleh para pelaksana yang bekerja sama dengan menggunakan kode sumber (source-code) yang terdapat dimana-mana. Database ini digunakan bersamaam dengan script PHP.

MySQL sering digunakan oleh pengembang web dikarenakan MySQL tersaji dalam bermacammacam program dan sesuai dengan berbagai sistem operasi. Fitur didalam MySQL merupakan fitur yang dibutuhkan dalam pengembangan aplikasi web. MySQL mempunyai kecepatan perpautan yang tinggi dikarenakan memiliki overhead yang rendah.

Sedangkan didalam jurnal Sugiyanto (2013) mengatakan bahwa menurut Gunawan (2012) MySQL (My Structure Query Language) merupakan sebuah sistem untuk mengorganisasi suatu database atau manajemen data untuk menyimpan semua informasi dengan mengunakan data. MYSQL bertanggung jawab mengkategorikan dan mengoperasikan data didalam database. MYSQL juga disebut sebagai sebuah sistem yang efektif dan teruji, proses query yang cepat dan mudah sangat tepat untuk digunakan dalam aplikasi berbasis web.

Sebelum mengembangkan sebuah website, seorang pengembang harus mengetahui tujuan dari pembuatan website. Hal tersebut wajib diketahui dikarenakan akan menentukan model website yang digunakan. Model website tersebut antara lain website dinamis dan website statis.

Menurut Harminingtyas (2014) website mempunyai sifat statis apabila isi informasi website tetap, jarang berubah, dan isi informasinya searah hanya dari pemilik website. Bersifat dinamis apabila isi informasi website selalu berubah-ubah, dan isi informasinya interaktif dua arah berasal dari pemilik serta pengguna website. Contoh website statis adalah berisi profil perusahaan, sedangkan website dinamis adalah seperti Friendster, Multiply, dll. Dalam sisi pengembangannya, website statis hanya bisa diupdate oleh pemiliknya saja, sedangkan website dinamis bisa diupdate oleh pengguna maupun pemilik.

Website statis yang hanya akan ada perubahan jika pengembang program menghendaki perubahan, menyebabkan beberapa pengguna akan mengalami kebosanan atau ketidak tertarikan.

Mengacu kepada hal tersebut, diperlukan website dengan design yang menarik sesuai dengan maksut dan tujuan website tersebut dibuat.

Didalam membuat website ada beberapa komponen yang wajib dimengerti untuk dapat mengembangkan website dengan desain yang maksimal. Markey (2019) memaparkan beberapa komponen untuk mendesain sebuah website. Komponen-komponen tersebut adalah tujuan pembuatan website, kebutuhan pengguna, kemudahan pengembangan berkelanjutan. Selain komponen-komponen tersebut, terdapat beberapa hal-hal penting yang juga harus dimengerti dalam mendesain website. Hal tersebut sangat diperlukan dalam menciptakan sebuah website yang sesuai dengan tujuannya. Dibawah ini juga terdapat beberapa hal yang perlu dimengerti dalam pengembangan desain website yang disampaikan oleh Markey (2019) yaitu tampilan website yang apik, halaman website yang menyatu, terdapat sitemap atau peta, tidak terdapat script yang berat, dapat diakses oleh semua jenis browser, loading yang cepat, navigasi yang simpel, konten yang berkualitas dan mudah dibaca. 
Terdapat beberapa hasil penelitian supervisi pendidikan yang bagi penulis relevan dengan penelitian ini. Diantaranya, Rachmati (2016) tentang Pengaruh Supervisi Pendidikan Terhadap Kinerja Guru Pada Sekolah Dasar di Lingkungan Dinas Pendidikan Kota Bandung Gugus 19 dan 20 Kota Bandung, menyatakan bahwa supervisi pendidikan yang dilakukan oleh supervisor memberikan pengaruh yang baik dan signifikan terhadap perubahan kinerja guru. Ini ditunjukkan dengan hasil uji $\mathrm{F}$ sebesar 18,595 yang berarti signifikan. Disini dinyatakan bahwa supervisi sangatlah penting dalam meningkatkan kualitas sebuah sekolah.

Sependapat dengan hasil penelitian diatas, hasil penelitian Manullang (2017) menyatakan bahwa diketemukan korelasi positif yang signifikan antara supervisi pengawas dengan kinerja Kepala Sekolah. Disini juga dituliskan bahwa strategi bimbingan supervisi yang belum memadai yang telah dilaksanakan oleh pengawas sekolah mengurangi kinerja kepala sekolah.

Penelitian yang dilakukan oleh Mergeritha (2013), tentang pemodelan sistem informasi penilaian kinerja kepala sekolah berbasis web. Penelitian ini mengembangkan aplikasi yang dibangun mudah dan praktis penggunaannya. Disamping itu juga mempercepat pekerjaan dalam melakukan penilaian kinerja kepala sekolah pada lingkup wilayah binaan yang ada. Sebelum aplikasi ini dibangun, rata-rata waktu yang dibutuhkan melakukan penilaian kinerja adalah tiga minggu, dengan menggunakan aplikasi ini waktu yang digunakan menjadi lebih cepat yaitu satu sampai dua minggu saja.

Menguatkan penelitian diatas, Rivalina (2017) dalam jurnalnya bahwa pemanfaatan e-learning dapat membantu mengatasi kekurangan tenaga dosen. Rivalina (2017) mengatakan bahwa dengan bertambahnya jumlah mahasiswa harus diimbangi dengan penambahan jumlah dosen. Dan masalah tersebut dapat teratasi dengan menggunakan E-Learning. Dengan E-Learning dosen dapat menjalankan tugasnya tanpa harus menambah jumlah tenaga.

Watid (2017) dalam penelitiannya yang berjudul Perancangan Dan Pembuatan Sistem Informasi Supervisi Manajerial Dan Akademik Pengawas (Sismap) Berbasis Web Pada Pengawas Guru Pai Dan Madrasah Di Kabupaten Cilacap, mengatakan bahwa SISMAP Berbasis Web ini akan memperingan terselenggaranya proses kepengawasan, dalam melaksanakan supervisi yang menjadi tugas Pengawas PAI dan Pengawas Madrasah di Kabupaten Cilacap.

Ditambahkan dengan hasil penelitian dari Machmud (2018), yang menyatakan bahwa sistem informasi memberikan dampak yang sangat besar terhadap kinerja dari pengguna sistem tersebut. Pengguna sistem informasi merasa puas dengan hasil kerjanya ditunjukan dengan total pengaruh dari variabel kualitas sistem (X1) terhadap kesuksesan sistem informasi (Y1) sebesar 0,689 dengan arah yang positif, terhadap kepuasan pengguna (Y2) sebesar 0,731.

Currin, et all (2019) dalam penelitiannya: Tinker, Tailor, Supervisor, Spy: Lessons Learned from Distant Supervision, mengatakan bahwa supervisi jarak jauh dan supervisi manual memiliki kelebihan dan kelemahannya sendiri-sendiri. Tantangan dan adaptasi diperlukan dalam pelaksanaan supervisi. Kesulitan dalam berkomunikasi, tidak adanya pengamatan dan juga pembinaan secara langsung membuat supervisi jaak jauh harus lebih disempurnakan lagi. Dengan menggandeng supervisi manual untuk melakukan supervisi jarak jauh akan menghasilkan supervisi yang benar-benar baik.

Susilowati (2017) yang menyelenggarakan penelitian tentang Model Supervisi Manajerial Pengawas Sekolah berbasis Kesejawatan menyatakan bahwa supervisi manajerial memerlukan keterbukan dalam mendiskusikan potensi dan kelemahan pengelolaan administrasi sekolah sehingga akan tercapai hasil supervisi yang baik dan transparan untuk kemajuan sekolah tersebut. Sehingga dapat dikatakan bahwa jika terjadi manipulasi data, supervisi manajerial berbasis kejawatan tidak dapat dilaksanakan.

Berbeda dengan hasil penelitian dari Wiguna (2017), yang menyatakan bahwa kinerja supervisi manajerial Kepala Sekolah Menengah Kejuruan Jurusan Teknologi Komputer Jaringan di Kabupaten Bandung mendapatkan skor tertinggi dari segi ketersediaan informasi, ketepatan informasi, kelengkapan informasi. Dari sini dapat disimpulkan bahwa semua data yang diperlukan adalah informasi yang sebenar-benarnya sesuai dengan keadaan dilapangan.

Sutanta (2005) menambahkan didalam penelitiannya tentang Dukungan Sistem Informasi Manajemen (SIM) dalam kegiatan Manajemen, SIM memberikan dukungan dalam pembuatan keputusan dengan memberikan basis data yang lengkap dan mempunyai kemampuan pencarian data dari basis data. 
Hasil yang sama terdapat dalam penelitian Lipursari (2013), yang menyatakan bahwa sistem informasi mutlak diperlukan dalam pengambilan keputusan yang logis. Sistem informasi memberikan informasi yang akurat, tepat waktu dan relevan.

Sejalan dengan penelitian diatas, peneliti yang melihat kondisi pengawas TK di kota Salatiga yang hanya terdiri dari 2 personil, tidak memungkinkan dapat menjalankan tugas secara maksimal. Peneliti ingin membantu meringankan tugas pengawas TK dalam pelaksanaan supervisi manajerial kepala TK dengan mengembangkan InPeSiM.

Dari pembahasan diatas, dapat disimpulkan sebagai berikut : kinerja pengawas sangat memegang peranan penting didalam perkembangan sebuah sekolah. Pengawas yang melakukan tugas supervisinya sesuai dengan tupoksinya, akan meningkatkan mutu TK binaan. Dan jika mutu sekolah baik, dapat dipastikan mutu pendidikan pada jenjang TK akan berkualitas juga. Akan tapi dengan beban yang tidak sesuai dengan jumlah personel akan berdampak negatif dengan kinerja seorang pengawas.

Jumlah pengawas yang tidak berbanding dengan jumlah TK binaan juga menjadi kendala dalam penilaian supervisi manajerial. Tidaklah hal yang mudah untuk mendapatkan seseorang duduk di kursi pengawas TK. Untuk membantu mengatasi masalah ini, peneliti mengembangkan InPeSiM.

Sebuah kerangka berpikir dapat digambarkan sebagai berikut: Analis kebutuhan Pengawas TK menyatakan Instrumen penilaian supervisi manajerial yang masih manual mengakibatkan pelaksanaan supervisi manajerial tidak maksimal, sehingga dibutuhkan instrumen supervisi manajerial yang dapat memaksimalkan pelaksanaan supervisi manajerial. Sehingga perlu dikembangkan sebuah instrumen penilaian supervisi manajerial.

Peneliti mengembangkan instrument supervisi manajerial berbasis website karena Watid (2017) dalam penelitiannya yang berjudul "Perancangan Dan Pembuatan Sistem Informasi Supervisi Manajerial Dan Akademik Pengawas (Sismap) Berbasis Web Pada Pengawas Guru Pai Dan Madrasah Di Kabupaten Cilacap", menjelaskan dalam penelitiannya bahwa SISMAP Berbasis Web memperingan pelaksanaan supervisi.

Setelah instrumen dikembangkan dilaksanakan validasi. Peneliti melakukan validasi kepada beberapa validator guna mendapatkan saran dan masukan terhadap instrumen penilian supervisi manajerial berbasis website. Hasil validasi ada dua kemungkinan yaitu layak dan tidak layak. Jika tidak layak maka penelitain dan pengembangan tidak dapat dilanjutkan.

Ketika dinyatakan layak, peneliti melakukan uji coba instrumen penilaian supervisi manajerial berbasis website kepada pengawas TK dan Kepala Sekolah TK.

Perumusan masalah dari penelitian ini adalah produk apa yang dapat memperingan tugas pengawas TK dalam pelaksanaan penilaian supervisi manajerial sehingga dapat berjalan dengan baik?. Dan yang menjadi tujuan pengembangan adalah mengembangkan instrumen penilaian supervisi manajerial kepala sekolah PAUD berbasis website (InPeSiM) sehingga membantu memperingan tugas pengawas TK dalam pelaksanaan penilaian supervisi manajerial.

Manfaat penelitian secara praktis adalah InPESiM berguna bagi pengawas TK untuk mempermudah dan mempercepat kinerja Pengawas TK dan InPeSiM berguna dalam meningkatkan kinerja Pengawas TK di jajaran Dinas Pendidikan.Kajian pustaka berisi tentang: (1) teori yang berisi: deskripsi, analisis dan sintesis, pemikiran mutakhir tentang berbagai isu yang relevan dengan masalah yang diteliti beserta manfaat yang dijanjikan, (2) kajian hasil-hasil penelitian yang relevan, (3) kerangka pikir yang merupakan kajian teoritis tentang keterkaitan antar variabel dalam menjawab atau memecahkan permasalahan penelitian, (4) rumusan hipotesis dan atau pertanyaan penelitian

\section{METODE PENELITIAN}

Penelitian yang dilaksanakan merupakan penelitian dan pengembangan ( Research and Development ). Dimana penelitian ini menghasilkan produk dan menguji keefektifan produk. Model penelitian dan pengembangan yang digunakan dalam penelitian ini adalah model penelitian dan pengembangan pendidikan yang dikembangkan oleh Borg dan Gall, yang menyatakan bahwa "education research and development $(R \& D)$ is a process used to develop and validate educational production" (Brog and Gall, 1983).

Untuk menyingkat waktu penelitian, maka peneliti hanya melakukan penelitian hingga tahap ketujuh dari model Research and Development ini. Langkah tersebut adalah (1) penelitian dan 
pengumpulan data, (2) perencanaan, (3) pengembangan draft produk, (4) uji coba lapangan awal, (5) merevisi hasil uji coba, (6) uji coba lapangan awal, (7) penyempurnaan produk hasil uji lapangan.

Van den Akker dan Plomp (1999) mendeskripsikan penelitian pengembangan berdasarkan dua tujuan yaitu pengembangan prototype produk dan perumusan saran-saran metodologis untuk pendesainan dan evaluasi prototype produk tersebut. Sehingga dapat dikatakan bahwa dalam penelitian perancangan dan pembuatan penilaian supervisi manajerial berbasis website ini merupakan jenis penelitian pengembangan atau Development Research (DR), khususnya dalam pengembangan prototype produk dan kemudian menguji produk tersebut.

Untuk subjek penelitian ini adalah 2 pengawas TK yang membawahi TK di 4 kecamatan di kota Salatiga dan 8 kepala sekolah TK di Kota Salatiga. 8 Kepala TK dipilih untuk dijadikan sampling dalam penelitian ini. Dipilih 8 kepala TK yang mewakili 4 kecamatan. Satu kecamatan diwakili oleh 2 Kepala Sekolah TK. Karena supervisi yang dilakukan berbasis teknologi, dalam pemilihan samplingpun mengambil Kepala Sekolah TK yang dapat menggunakan IT dengan baik dan benar.

Teknik dan instrumen pengumpulan data menggunakan wawancara, yang dilakukan kepada Pengawas TK di kota Salatiga dan Kepala Sekolah binaan. Kuesioner juga disebarkan kepada Pengawas, Kepala Sekolah binaan. Tidak hanya itu, studi dokumen pun dilakukan untuk memperkaya data.

Data kualitatif divalidasi dengan menggunaan triangulasi data dan juga triangulasi sumber. Teknik ini digunakan untuk menghindari dari berbagai bias dan kekurangan yang bersumber dari pengandalan sumber data, peneliti, teori, dan metode yang tunggal.

Deskriptif kualitatif digunakan untuk menganalisis data penelitian. Pengkodean digunakan sehingga data dapat mudah diukur dan dipahami. Setelah proses pengkodean, tabulasi digunakan untuk menghitung data dari dari hasil pengkodean, kemudian disajikan dalam bentuk tabel. Skala Likert dalam angket diterjemahkan dengan menggunakan analsis interval.

\section{HASIL PENELITIAN DAN PEMBAHASAN Hasil Penelitian}

Pada tahap analisis potensi masalah dan pengumpulan data, peneliti mengumpulkan data melalui wawancara terbuka dan studi dokumen. Sasaran dari wawancara ini adalah Pengawas TK Kecamatan Tingkir dan Kepala Sekolah di paguyuban MKKS Kota Salatiga. Wawancara terbuka dan studi dokumen ini dilaksanakan untuk mengetahui gambaran pelaksanaan penilaian supervisi manajerial yang dilakukan oleh Pengawas TK. Hasil analisis data dari wawancara terbuka dengan Pengawas TK Kecamatan Tingkir, menyatakan bahwa penilaian supervisi manajerial yang dilaksanakan oleh Pengawas TK dilaksanakan secara manual. Pengawas TK Kecamatan Sidorejo juga menyampaikan bahwa proses supervisi yang dilaksanakan oleh Pengawas TK adalah sebagai berikut, Pengawas TK harus melakukan visitasi ke lembaga PAUD. Didalam visitasi tersebut, pengawas meminta kepala sekolah untuk menyiapkan semua dokumen yang akan diperiksa. Penilaian dilakukan secara manual dengan cara mengisikan poin-poin dari instrumen yang tertera dibuku penilaian.

Keunggulan dari pelaksanaan supervisi manajerial yang dilakukan oleh Pengawas TK saat ini adalah dapat melihat secara langsung kondisi dari lembaga yang disupervisi. Sedangkan kelemahan didalam pelaksanaan supervisi manajerial yang dilaksanakan Pengawas TK saat ini adalah (1) supervisi manajerial tidak memungkin untuk dilaksanakan bagi seluruh TK di Kota Salatiga disebabkan oleh minimnya jumlah pengawas TK di Kota Salatiga, (2) proses supervisi yang membutuhkan waktu yang cukup lama, (3) banyaknya dokumen pelengkap yang harus diperiksa oleh Pengawas TK sehingga Pengawas mengungkapkan kekurangan waktu dan tenaga dalam pelaksanaan supervisi manajerial, (4) Perolehan hasil supervisi dan tindak lanjut dari supervisi yang tidak dapat disampaikan dengan cepat.

Wawacara, studi dokumen dan penyebaran angket digunakan untuk mengumpulkan data. Dari hasil pengumpulan data ditemukan bahwa Pengawas TK membutuhkan instrumen penilaian supervisi manajerial yang memiliki efisiensi waktu dan tenaga. Menjawab kebutuhan tersebut, peneliti menggunakan model Borg dan Gall. Pemilihan model pengembangan mengacu pendapat Bukhari (2016) yang menyatakan bahwa model Borg and Gall memiliki kelebihan seperti mampu menghasilkan produk yang memiliki validasi tinggi karena pengembangan melewati proses validasi ahli dan uji coba lapangan. Akan tetapi dikarenakan model pengembangan Borg dan Gall membutuhkan waktu yang lama (Hanafi, 2017), peneliti hanya membatasi pengembangan sampai pada tahap ke tujuh. Mengacu kepada hasil penelitan Watid (2017) yang menyatakan bahwa website sangat membantu kinerja 
pengawas, didalam pengembangan instrumen penilaian supervisi manajerial inipun mengembangkan sebuah website statis. Buku panduan juga dikembangkan untuk melengkapi website ini.

Pengembangan instrument supervisi manajerial kepala sekolah PAUD berbasis website atau InPeSiM dilaksanakan untuk membantu tugas pengawas terkhususnya dalam pelaksanaan supervisi manajerial dapat diselenggarakan secara maksimal di kota Salatiga. Peneliti menyusun produk yang berupa prototipe dan buku panduan. Prototipe berupa aplikasi dalam website yang menggunakan aplikasi XAMPP. XAMPP merupakan aplikasi server lokal yang berguna sebagai penyimpanan sementara server. Website didesain untuk dapat diakses melalui berbagai browser. InPeSiM mempunyai dua tampilan aplikasi yaitu aplikasi untuk pengawas TK yang disebut sebagai administrator dan aplikasi untuk kepala sekolah yang nantinya akan disebut sebagai user.

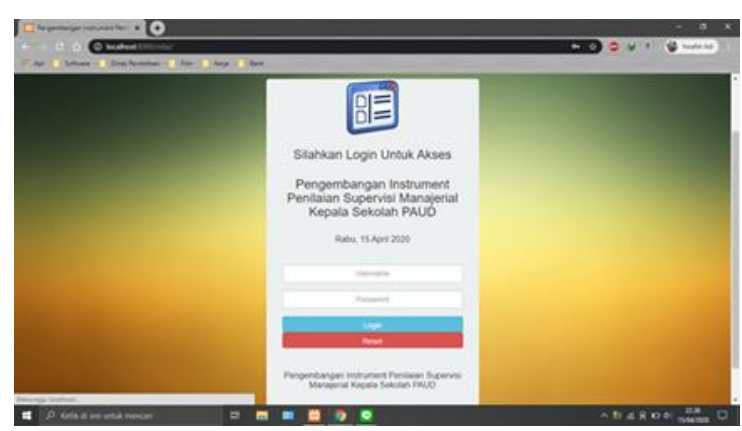

Gambar 1. Tampilan saat Loggin di InPeSiM

Kedua aplikasi berisi 9 indikator penilaian supervisi manajerial beserta butir-butir penjelasnya. Fungsi pengunggahan dokumen supervisi juga terdapat didalam aplikasi ini.

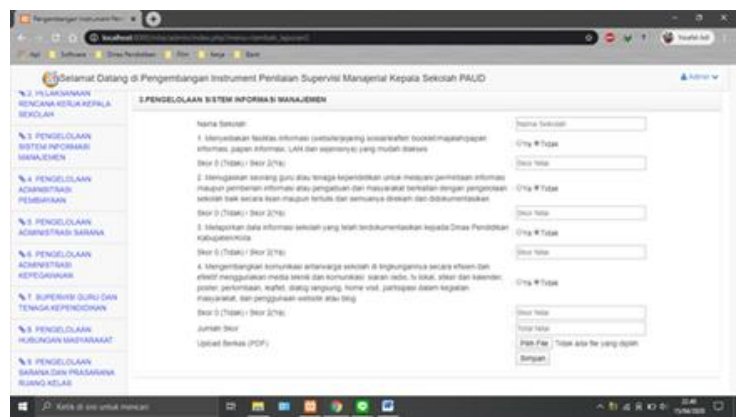

Gambar 2. Tampilan indikator penilaian beserta butir penjelasnya

Sedikit berbeda dengan user, administrator memiliki tambahan fungsi yaitu rekap penilaian seluruh TK dan hasil penilaian akhir InPeSiM.

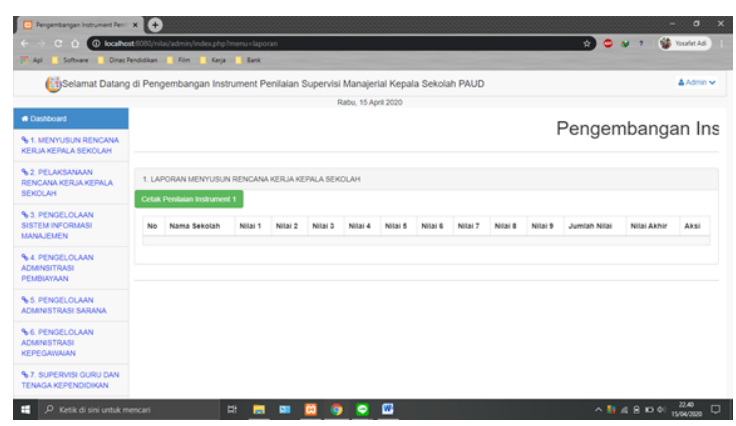

Gambar 3. Tampilan fungsi rekap nilai 


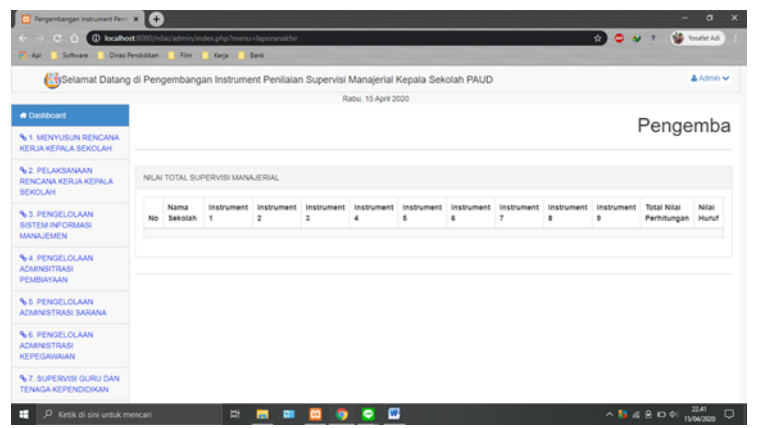

Gambar 4. Tampilan fungsi hasil penilaian akhir

Buku paduan disusun untuk melengkapi ImPeSiM. Disini peneliti menyusun dua buku panduan. Yang pertama adalah buku panduan untuk pengawas dan yang kedua adalah buku panduan untuk kepala sekolah. Buku panduan disusun untuk membantu pengawas dan kepala sekolah dalam penggunaan instrumen ini

Hasil validasi dari ahli supervisi manajerial menunjukkan nilai rerata 8,9 yang dapat ditarik kesimpulan bahwa InPeSiM yang disusun sangat lengkap dan dapat digunakan.

Sedangkan ahli IT menjelaskan bahwa website dapat digunakan tanpa ada kendala yang begitu menganggu. Rata-rata yang ditampilkan adalah 9,2 dengan kriteria Sangat Setuju. Dapat ditarik kesimpulan bahwa validator sangat setuju website ini digunakan untuk penilaian supervisi manajerial kepala sekolah PAUD.

Pada tahap revisi produk ini, peneliti telah melakukan revisi berdasarkan masukan dari validator ahli supervisi dan validator ahli IT. Revisi dilakukan dengan menyempurnakan prototipe dan buku panduan sehingga dapat diujicobakan pada tahap selanjutnya.

Ujicoba produk dilaksanakan oleh 2 pengawas dan 8 Kepala Sekolah di Kota Salatiga. Pertamatama yang dilakukan peneliti adalah menjelaskan kegunaan instrumen, kemudian menjelaskan bagaimana cara mengisi penilaian supervisi manajerial sesuai dengan buku panduan. Pada tahap pengujian produk, website masih menggunakan lokal hosting, sehingga untuk penggunaannya, para pengguna website mengundang alamat yang telah ditentukan.

Setelah selesai mengisi InPeSiM, Kepala Sekolah mengisi angket yang sudah disediakan oleh peneliti. Hasil dari uji lapangan dapat dilihat dari tabel dibawah ini

Tabel 1. Hasil Uji lapangan Bagi Kepala TK

\begin{tabular}{clcc}
\hline No & \multicolumn{1}{c}{ Indikator } & Score & Kriteria \\
\hline 1 & Layout website rapi serta enak dilihat & 33 & $\mathrm{SS}$ \\
\hline 2 & Tidak ada absen script yang dirasa membebani website & 33 & $\mathrm{SS}$ \\
\hline 3 & Website ini compatible untuk semua jenis browser & 33 & $\mathrm{SS}$ \\
\hline 4 & Dalam mengakses website memiliki loading yang cepat & 36 & $\mathrm{SS}$ \\
\hline 5 & Konten website berkualitas dan mudah dibaca & 36 & $\mathrm{SS}$ \\
\hline 6 & Website mudah digunakan & 40 & $\mathrm{SS}$ \\
\hline 7 & Warna website menarik & 36 & $\mathrm{SS}$ \\
\hline 8 & Font yang digunakan sesuai & 36 & $\mathrm{SS}$ \\
\hline 9 & Gambar yang digunakan dalam website sesuai & 36 & $\mathrm{SS}$ \\
\hline 10 & Website ini mempermudah supervisi manajerial & 40 & $\mathrm{SS}$ \\
\hline 11 & Penilaian supervisi manajerial berbasis website bermanfaat untuk & 39 & $\mathrm{SS}$ \\
& pengembangan lembaga PAUD & & \\
\hline & Rata-rata & 36,18 & $\mathrm{SS}$ \\
\hline
\end{tabular}

Keterangan Kriteria:

34-40 Sangat Setuju (SS)

25-32 Setuju (S)

17-24 Kurang Setuju (KS)

9-16 Tidak Setuju (TS)

0-8 Sangat Tidak Setuju (STS) 
Dari tabel 1 diketahui bahwa nilai rata-rata 36,18 terdapat pada interval 34-40 dalam kategori sangat setuju. Menurut Kepala Sekolah TK, InPeSiM dapat digunakan sebagai instrumen penilaian supervisi manajerial.

Tabel 2. Hasil Uji lapangan Bagi Pengawas TK

\begin{tabular}{clcc}
\hline No & \multicolumn{1}{c}{ Indikator } & Score & Kriteria \\
\hline 1 & Tampilan website rapi serta enak dilihat & 9 & SS \\
\hline 2 & Loading dari website cepat & 9 & SS \\
\hline 3 & Website ini mudah digunakan & 10 & SS \\
\hline 4 & Konten website ini berkualitas dan mudah dibaca & 9 & SS \\
\hline 5 & Website ini mempermudah supervisi manajerial & 10 & SS \\
\hline 6 & Website ini membantu tugas pengawas dalam pelaksanaan supervisi manajerial & 9 & SS \\
\hline & Rata-rata & 9,33 & SS \\
\hline
\end{tabular}

Keterangan Kriteria:

8,1-10 Sangat Setuju (SS)

7,1-8 Setuju (S)

6,1-7 Kurang Setuju (KS)

5,1-6 Tidak Setuju (TS)

0-5 Sangat Tidak Setuju (STS)

Tabel 2 memperlihatkan bahwa rata-rata 9,33 pada interval 8,1-10 dalam kategori SS. Hal ini dapat diartikan bahwa dari sudut pandang pengawas TK Kota Salatiga, InPeSiM sangat setuju untuk dapat digunakan dalam pelaksanaan supervisi manajerial kepala sekolah PAUD. Tahap terakhir dari penelitian pengembangan ini adalah revisi produk. Pada saat prototipe diujicobakan di tahap sebelumnya, peneliti mendapatkan banyak sekali masukan dari Pengawas TK dan juga Kepala Sekolah. Revisi produk dilakukan berdasarkan masukan dan saran dari Kepala Sekolah dan Pengawas pada saat uji coba. Revisi tersebut meliputi penambahan fungsi pada database sehingga pengawas dan kepala sekolah dapat mengambil kembali data yang telah di input dan penambahan fungsi chat sehingga memungkinkan feedback yang cepat oleh pengawas dan kepala sekolah. Setelah dilakukan revisi, InPeSiM dapat digunakan dan bisa direkomendasikan untuk diujicobakan dalam skala besar. Namun karena dalam penelitian pengembangan ini dibatasi hingga tahap ketujuh, tahap ini menjadi tahap terakhir dari penelitian pengembangan ini.

\section{Pembahasan}

Hasil wawancara dengan Pengawas TK dan Kepala TK di Kota Salatiga, peneliti mendapatkan penjelasan bahwa supervisi manajerial Kepala Sekolah PAUD dilaksanakan secara tatap muka. Pengawas harus menempuh jarak tertentu untuk dapat melaksanakan supervisi tersebut. Pengawas harus hadir di sekolah yang akan disupervisi.

Dikatakan di dalam PP no 74 tahun 2008 bahwa tugas Pengawas TK melakukan pengawasan dan membina paling sedikit 10 sekolah dan paling banyak 15 sekolah. Jumlah personil Pengawas TK adalah 2 orang sedangkan jumlah TK binaan di kota Salatiga berjumlah 85 TK, sehingga rasionya 1:43. Seharusnya dengan jumlah TK 85 diperlukan pengawas 8 atau 9 orang. Jadwal kunjungan dalam rencana kerja Pengawas TK dikatakan hanya dapat mengunjungi 10 TK disetiap tahunnya. Ini mengakibatkan supervisi manajerial tidak dapat dilaksanakan secara maksimal

Hal ini sejalan dengan hasil penelitian Slameto (2016) tentang Supervisi Pendidikan Oleh Pengawas Sekolah yang menyatakan bahwa kurangnya tenaga pengawas menyebabkan beberapa kendala dalam melaksanakan tugas pengawas sebagai supervisor.

Selanjutnya instrumen penilaian yang masih dilaksanakan secara manual menyebabkan pengawas TK harus mengagihkan waktu khusus untuk dapat menilai semua instrumen supervisi manajerial. Beban administrasi yang sangat banyak, tidak memungkinkan untuk seorang pengawas menilai secara maksimal.

Kondisi diatas sangat mempengaruhi kinerja seorang pengawas. Kondisi tersebut tidak dapat mewujudkan yang seperti disebutkan di Peraturan Menteri Pendidikan dan Kebudayaan Nomor 143 tahun 2014 tentang Petunjuk Teknis Pelaksanaan Jabatan Fungsional Pengawas Sekolah Dan Angka Kriditnya yaitu bahwa pengawas mempunyai kewajiban untuk melaksanakan tugasnya secara baik dan maksimal dalam upaya meningkatkan mutu dan kinerja sekolah. 
Supervisi sangat dibutuhkan untuk perkembangan sekolah. Sebuah sekolah tidak dapat mengalami peningkatan jika supervisi tidak dilakukan secara maksimal. Pengaruh supervisi sangat besar dampaknya terhadap perkembangan sekolah itu sendiri. Astuti (2017) dalam jurnalnya mengatakan bahwa supervisi harus dilaksanakan secara intensif dan berkelanjutan, sehigga kinerja guru dapat meningkatkan kualitas sekolah. Oleh sebab itu, seorang supervisor didalam melaksanakan tugasnya sangat membutuhkan dukungan dan bantuan dari berbagai pihak, termasuk di dalamnya teknologi.

Dengan memanfaatkan teknologi diharapkan akan memperingan pelaksanaan tugas pengawas sebagai supervisor. Untuk itu, perlu dikembangkan instrumen penilaian supervisi manajerial. Instrumen tersebut adalah instrumen penilaian supervisi manajerial kepala sekolah PAUD berbasis website atau InPeSiM. Pengembangan InPeSiM dilaksanakan dalam 7 tahap dari pengembangan model Borg and Gall yang dimodifikasi Sugiyono. Tahapan tersebut adalah tahap analisis potensi dan masalah, pengumpulan data, desain produk, validasi desain, revisi desain, uji coba produk dan tahap revisi produk (Sugiyono, 2010). Tahap analisis potensi masalah dan pengumpulan data dilaksanakan untuk mengetahui masalah yang terjadi dilapangan sehingga dapat digunakan untuk menentukan langkah selanjutnya. Sugiyono (2010) juga mengatakan didalam tahap ini juga dapat untuk merumuskan kerangka kerja penelitian termasuk dalam langkah ini merumuskan kecakapan dan keahlian yang berkaitan dengan permasalahan. Setelah menemukan permasalahan dan data yang diperlukan, penelitian melangkah ke tahap selanjutnya.Hasil dari tahap analisis potensi masalah dan pengumpulan data digunakan sebagai dasar dari tahap pembuatan desain produk. Di tahap desain produk, peneliti mengembangkan sebuah website. Sebagai pengembangan Website digunakan MySQL dan aplikasi XAMPP. XAMPP adalah aplikasi server lokal.

Berbeda dengan penelititan Fadli (2014), yang menggunakan webhosting dimana web memanfaatkan langganan hosting berbayar, InPeSiM hanya menggunakan localhosting. Untuk desain website dikembangkan sesuai dengan kebutuhan pengguna yaitu pengawas TK. Sejalan dengan pendapat Markey (2019) yang menyatakan bahwa pembuatan website harus terlebih dahulu mengetahui tujuan dan kebutuhan pengguna. Tujuan dan kebutuhan yang berbeda akan membutuhkan desain yang berbeda pula.

Setelah tahap pengembangan desain produk, InPeSiM diujicobakan oleh beberapa ahli. Hasil uji validitas IT berada direrata 9,2 dengan kriteria Sangat Setuju. Dapat disimpulkan bahwa instrumen penilaian berbasis website dapat digunakan untuk penilaian supervisi manajerial.

Sejalan dengan Watid (2017) dalam penelitiannya menyatakan bahwa SISMAP dapat digunakan dalam pelaksanaan supervisi manajerial dan akademik oleh pengawas Kabupaten Cilacap.

Delapan Kepala Sekolah dan Pengawas TK di Kota Salatiga membantu dalam tahap uji coba produk. Tahap ini, 8 Kepala Sekolah menginput data dan juga mengunggah dokumen yang diperlukan. Kepala Sekolah tanpa harus melakukan tatap muka dengan pengawas diminta untuk mengisi instrumen penilaian, dan hasil input dokumen dan data siap untuk dinilai oleh pengawas. Pengawas yang memiliki banyak tugas dan kekurangan tenaga dalam melaksanakannya, dapat menyelesaikan tugas supervisi manajerial dengan cepat. Efisiensi waktu dan tenaga telah dinyatakan InPeSiM.

Sejalan dengan yang disampaikan oleh Rivalina (2017) dalam jurnalnya bahwa pemanfaatan E-learning dapat membantu mengatasi kekurangan tenaga dosen. Rivalina (2017) mengatakan bahwa dengan bertambahnya jumlah mahasiswa harus diimbangi dengan penambahan jumlah dosen. Dan masalah tersebut dapat teratasi dengan menggunakan E-Learning. Dengan E-Learning dosen dapat menjalankan tugasnya tanpa harus menambah jumlah tenaga.

Dikuatkan oleh Suhaeri (2019) dalam jurnalnya yang menyatakan bahwa menggunakan media E-Learning, proses belajar dan mengajar dapat dilaksanakan dimanapun dan kapanpun. Jelas disini dinyatakan bahwa penggunaan E-Learning memberikan efesiensi waktu dan tempat. Sejalan dengan Warschauser (2001) yang menyatakan bahwa daring memiliki keunggulan dibandingkan dengan komunikasi konvensional. Komunikasi daring dapat dilaksanakan tanpa adanya tatap muka. Dengan memakai teknologi, terkhususnya pelaksanaan supervisi secara online akan sangat membantu pengawas dalam mengerjakan tugas dan tanggung jawabnya. Para pengawas yang kekurangan waktu dan juga tenaga dapat melakukan supervisi secara online. Penilaian online juga tidak membutuhkan kehadiran pengawas secara fisik. Pengawas tidak perlu mengagihkan waktu khusus untuk dapat hadir di sekolah tersebut. Disamping itu dalam waktu yang bersamaan, supervisi dapat dilakukan oleh banyak kepala sekolah. Efisiensi waktu dan tenaga diberikan oleh penilaian secara online. Sejalan dengan hasil 
penelitian Sofyan (2014) yang menyatakan bahwa model pelatihan sistem manajemen mutu yang menggunakan website dikategorikan baik dan efektif untuk meningkatkan kompetensi karyawan dalam memberikan pelayanan. Dikuatkan oleh hasil penelitian Hamzah (2016) yang menyampaikan bahwa website sangat efektif untuk dapat dimanfaatkan dan memberikan dampak yang baik disalam proses pembelajaran. Sejalan dengan hasil penelitian diatas, hasil yang diperoleh dari uji lapangan yang dilakukan oleh pengawas TK menunjukkan rata-rata 9,33 dimana dapat diartikan bahwa InPeSiM dapat digunakan dan sangat membantu tugas dari pengawas TK terkhususnya didalam pelaksanaan supervisi manajerial.

\section{SIMPULAN DAN SARAN}

Produk yang dihasilkan dari penelitian pengembangan ini adalah Instrumen Penilaian Supervisi Manajerial Kepala Sekolah PAUD Berbasis Website yang diberi nama InPeSiM, panduan untuk guru dan panduan untuk Kepala Sekolah. InPeSiM memiliki dua aplikasi, yaitu bagi user dan admin. Didalam aplikasi terdapat 9 indikator penilaian supervisi manajerial kepala sekolah PAUD. Setiap indikator diikuti oleh butir-butir penjelas. Didalam aplikasi admin, terdapat beberapa perbedaan dengan aplikasi user, yaitu terdapat fungsi rekap nilai dan fungsi perolehan nilai akhir. Berdasarkan hasil validasi ahli, InPeSiM sudah dinyatakan sangat lengkap dan sangat setuju yang dibuktikan dari hasil validasi ahli memperoleh skor 8,9 dan 9,2. Sedangkan pada uji coba lapangan, InPeSiM dengan nilai 9.33, Pengawas TK menyatakan sangat setuju untuk menggunakan InPeSiM.

Saran dari peneliti bagi Pengawas TK di Kota Salatiga, InPeSiM dapat digunakan sehingga dapat mempermudah dan mempercepat kinerja pengawas TK di Kota Salatiga. Selanjutnya bagi Dinas Pendidikan, InPeSiM dapat digunakan untuk meningkatkan kinerja Pengawas TK di jajaran Dinas Pendidikan. Evaluasi Penggunaan Instrumen Supervisi Manajerial Kepala Sekolah PAUD Berbasis Website atau InPeSiM belum dapat terlaksana, sehingga bisa menjadi rekomendasi untuk penelitian selanjutnya.

\section{UCAPAN TERIMAKASIH}

Peneliti mengucapkan banyak terima kasih kepada Dr. Yari Dwikurnaningsih, M.Pd, selaku dosen pembimbing yang selalu mendukung dalam penulisan ini, Pengawas TK Kota Salatiga dan MKKS Kota Salatiga yang bersedia mendukung dalam proses uji coba dan pengumpulan data, dan juga para validator hebat, Dr Bambang Suteng Sulasmono, M.Si., Bapak Herry Sanoto,S.Si., M.Pd., Ibu Mila Chrismawati Pasaleng, S.S., M.Pd., Dr Sri Yulianto,J.P.,S.Si., M.Kom.

\section{DAFTAR PUSTAKA}

Arham, Uliya Ulil. (2016). Keefektifan Multimedia Interaktif Berbasis Blended Learning untuk Meningkatkan Hasil Belajar Siswa. Jurnal Kwangsan Vol. 4 No.2, Edisi Desember 2016. Retrieved from https://jurnalkwangsan.kemdikbud.go.id/index.php/jurnalkwangsan/article/view/89/68.

Arikunto, Suharsimi. (2006). Pengembangan Kapasitas Kepengawasan Pendidikan di Wilayah Kota Yogyakarta. Jurnal Penelitian Bappeda Kota Yogyakarta Vol. 1 No. 1 Desember 2006, hlm. 11.

Akker, Jan Van den. (1999). Principles and Methods of Development Research. Pada J. van den Akker, R.Branch, K. Gustafson, Nieven, dan T. Plomp(eds), Design Approaches and Tools in Education and Training (pp. 1-14). Dortrech: Kluwer Academic Publishers.

Astuti, Suhandi. 2017. Supervisi Akademik Untuk Menigkatkan Kompetensi Guru Di Sd Laboratorium Uksw. Scholaria: Jurnal Pendidikan dan Kebudayaan, Vol. 7 No 1, Januari 2017: 49 - 59. Retrieved from https://ejournal.uksw.edu/scholaria/article/view/713/477.

Baharudin, R. (2010). Keefektifan Media Belajar Berbasis Teknologi Informasi dan Komunikasi. Tadrîs, 5(1), 112-127 
Bukhari, Sayid. (2016). Penelitain Pengembangan (Research and Development) Model Borg and Gall. Retrieved from https://sayidbukhari.blogspot.com/2016/05/penelitian-pengembanganresearch-and.html.

Currin et.all, (2019). Tinker, Tailor, Supervisor, Spy: Lessons Learned from Distant Supervision. Journal of Educational Supervision 78 - 97 Volume 2, Issue 1, 2019. Retrieved from https://doi.org/10.31045/jes.2.1.5

Kementrian Pendidikan dan Kebudayaan Direktorat Jenderal Guru dan Tenaga Kependidikan Direktorat Pembinaan Tenaga Kependidikan. (2018). Modul Pengelolaan Supervisi Manajerial Pendidikan dan Pelatihan Fungsional Calon Pengawas sekolah dan Penguatan Kompetensi Pengawas Sekolah. Retrieved from http://p4tkbahasa.kemdikbud.go.id/wpcontent/uploads/2019/06/B2-Pengelolaan-Supervisi-Manajerial-061118.pdf.

Kementerian Pendidikan dan Kebudayaan. (2014). Peraturan Menteri Pendidikan dan Kebudayaan nomor 143 tahun2014 tentang petunjuk teknis Pelaksanaan Jabatan Fungsional Pengawas Sekolah Dan Angka Kreditnya.

Fadli. (2014). Pengembangan Model Pembelajaran Berbasis Web untuk Pelajaran Matematika. Jurnal Teknologi Pendidikan Vol.16.No 1. April 2014. Retrieved from http://journal.unj.ac.id/unj/index.php/jtp/article/view/5400/4029.

Hanafi. (2017). Konsep Penelitin R\&D dalam Bidang Pendidikan. Saintifika Islamica:Jurnal Kajian Keislaman Vol. 4 No.2 Juli-Desember 2017. Retrieved from http://jurnal.uinbanten.ac.id/index.php/saintifikaislamica/article/view/1204.

Harminingtyas, Rudika. (2014). Analisis Layanan Website sebagai Media Promosi, Media Transaksi dan Media Informasi dan Pengaruhnya terhadap Brand Image Perusahaan pada Hotel Ciputra di Kota Semarang. Jurnal STIE Semarang, Vol 6, No 3, Edisi Oktober 2014. Retrieved from http://jurnal3.stiesemarang.ac.id/index.php/jurnal/article/view/120.

https://markey.id/development/website-design diunduh pada tanggal 23 Juli 2019.

Istiyarti. ( 2014). Pemanfaatan TIK untuk Pembelajaran. Jurnal Kwangsan, Vol. 2, No 1 (2014). Retrieved from https://jurnalkwangsan.kemdikbud.go.id/index.php/jurnalkwangsan/article/view/15/14.

Lipursari, Anastasia. (2015). Peran Sistem Informasi Manajemen (Sim) Dalam Pengambilan Keputusan. Jurnal STIE Semarang. Vo; 5. No.1. Edisi Februari 2013. Retrieved from https://media.neliti.com/media/publications/132855-ID-peran-sistem-informasi-manajemensim-dal.pdf.

Machmud, Rizan. (2018). Kepuasan Penggunaan Sitem Informasi (Studi Kasus pada T3- Online). Jurnal Manajemen Vol XVIII, No. 02, Juni 2014:295-306. Retrieved from http://repository.ung.ac.id/get/karyailmiah/2450/Rizan_Machmud__Buku_Kepuasan_Peng gunaan_Sistem_Informasi.pdf.

Madcoms. (2011). Aplikasi Web Database CSS PHP-MySQL untuk Pemula. Yogyakarta: Andi.

Manullang, Jongga. (2017). Efektifitas Model Supervisi Manajerial bagi Kepala Sekolah. Jurnal Generasi Kampus Vol 10, No 2, September 2017. Retrieved from https://docplayer.info/storage/107/176507628/176507628.pdf

Margaritha. (2015). Pemodelan sistem informasi penilaian kinerja kepala sekolah berbasis web. Retrieved from http://repository.uksw.edu/bitstream/123456789/6362/2/T1_672007074_Full\%20text.pdf.

Prasojo,Lantip Diat. (2005). Sistem Informasi Manajemen dalam Pembelajaran. Majalah Ilmiah Pembelajaran no.2 Vol 1. Oktober 2005. Retrieved from http://staff.uny.ac.id/sites/default/files/Sistem\%20informasi\%20Manajemen\%20dalam\%20Pe mbelaajran.pdf.

Presiden Republik Indonesia. (2008). Peraturan Pemerintah no 74 tahun 2008 tentang Guru. 
Pengembangan Instrumen Penilaian Supervisi Manajerial Kepala Sekolah PAUD Berbasis Website (Dian Widi Yussanti, Yari Dwikurnaningsih)

Rachmawati, Tuti. (2016). Supervisi Pendidikan Sebagai Upaya Meningkatkan Kinerja Guru. Coopetition, Vol VII, Nomor 1, Maret 2016, 43 - 52. Retrieved from http://ikopin.ac.id/jurnal/index.php/coopetition/article/download/10/10.

Rivalina, Rahmi. (2016). Strategi Pemanfaatan E-Learning Dalam Mengatasi Keterbatasan Jumlah Dosen. Jurnal Kwangsan, Vol 5, No 2 (2017). Retrieved from https://jurnalkwangsan.kemdikbud.go.id/index.php/jurnalkwangsan/article/view/46.

Rochaety, Ety dkk. ( 2006). Sistem Informasi Manajeman Pendidikan. Jakarta: Bumi Aksara.

Slameto. (2016). Supervisi Pendidikan Oleh Pengawas Sekolah. Jurnal Kelola, Vol. 3, No. 2, JuliDesember 2016.

Shinta, Dyah Ayu. (2015). Pelaksanaan Supervisi Paud Oleh Pengawas Uppd Kecamatan Tegal Barat Di Taman Kanak-Kanak Little Star Tegal. Retrieved from https://lib.unnes.ac.id/22602/1/1601410011-s.pdf.

Sofyan. (2014). Pengembangan Model Pelatihan Sistem Manajemen Mutu Berbasis Website. Jurnal Teknologi pendidikan Vol. 16. No. \#. Desember 2014. Retrieved from http://journal.unj.ac.id/unj/index.php/jtp/article/view/5416/4049.

Sugiyanto. (2013). Pembuatan Website Profil Sekolah Menengah Kejuruan Pembangunan Nusantara Gabus Grobogan. seruniid.unsa.ac.id. 2(1), 57.

Sugiyono. (2010). Metode Penelitian Pendidikan: Pendekatan Kuantitatif, Kualitatif dan R\&D. Bandung: Alfabeta.

Suhaeri, Totok. (2019). Edmodo Based e-Learning Development on Science Lesson in 7th Grade. Scholaria: Jurnal Pendidikan dan Kebudayaan, Vol. 10 No. 1, Januari 2020: 34-41. Retrieved from https://ejournal.uksw.edu/scholaria/article/view/2590/1371.

Susilowati, Kartika. (2017). Pengembangan Model Supervisi Manajerial Pengawas Sekolah berbasis Kesejawatan. Jurnal Education Mangement 6(1)(2017)80-86. Retrieved from https://journal.unnes.ac.id/sju/index.php/eduman/article/view/16469.

Sutanta, Edhy. (2005). Dukungan Sisitem Informasi Manajemen (SIM) dalam Kegiatan Manajemen. Jurnal Ilmiah Manajerial. Vol.1 No. Maret 2005. Retrieved from https://www.academia.edu/6023886/Jurnal_MANAJERIALDUKUNGAN_SISTEM_INFORMASI_MANAJEMEN_SIM_DALAM_KEGIATAN_MAN AJEMEN.

Syawal, Julkarnain. (2013). Evaluasi Kinerja Pengawas Sekolah Dalam Melakukan Supervisi Penyelenggaraan Pendidikan SD di Kota Tidore Kepulauan. Retrieved from http://journal.student.uny.ac.id/ojs/index.php/jep/article/view/67.

Walter R. Borg \& Meredih D. Gall. (1983). Educational Research: An Introduction. New York: Longman.

Warschauer, M. (2001). Online communication. In R. Carter \& D. Nunan (Eds.), The Cambridge guide to teaching English to speakers of other languages (pp. 207-212). Cambridge: Cambridge University Press. Retrieved from http://education.uci.edu/uploads/7/2/7/6/72769947/online_communication.pdf.

Watid, Asas. (2017). Perancangan Dan Pembuatan Sistem Informasi Supervisi Manajerial Dan Akademik Pengawas (Sismap) Berbasis Web Pada Pengawas Guru Pai Dan Madrasah DiKabupaten Cilacap. Retrieved from http://repository.iainpurwokerto.ac.id/compressed.pdf.

Wiguna, Windu. (2017). Kinerja Manajerial, Pemanfaatan Sistem Informasi Manajemen Sekolah dan Efektifitas Implementasi Rencana Stratejik. Jurnal Administrasi Pendidikan Vol.XXXIV No.1 April 2017. Retrieved from https://media.neliti.com/media/publications/74616-ID-kinerjamanajerial-pemanfaatan-sistem-in.pdf. 